症例

直腸粘膜下腫瘍の形態をとった骨盤内デスモイドの 1 例

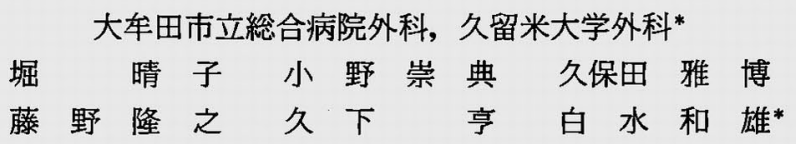

症例は 50 歳, 女性. 鵎卵大の右智部腫瘤を自賞. 皮凮科を受診し MRI 検査で骨盤内腫 場と診断され当科紹介入院となった。

大腸内視鏡, 注腸造影検查, CT 検查で腹膜翻転部付近の直腸右側に $8 \times 5 \times 8 \mathrm{~cm}$ の 腫瘍を認めた。術前診断として脂肪腫，脂肪肉腫，平滑筋肉腫などを考え開腹術を施行 した. 腫崵は腹膜翻転部より下方, 直腸の右側を中心に存在し比較的容易に切除できた. 腫湯は白色調, 弾性硬の球状腫瘤で, 病理組織像では線維芽細胞と膠原瀻維が主体であ りデスモイド腫瘍と診断された。デスモイド腫場が直腸近傍に発生し粘膜下腫湟の形態 を呈した症例はわれわれが検索したかぎりではなかった。

索引用語：骨盤内デスモイド

\section{緒言}

デスモイドは筋膜や腱膜などの間葉系から発生する 比較的稀な軟部組織腫瘍で良性で転移はしないが, 浸 潤性に発育し局所再発をおこしやすい. 発生部位によ って腹壁, 腹壁外, 腹空内 (腸間膜, 骨盤腔) デスモ イドに分類される゙1. 今回われわれは, 肛門挙筋もしく は直腸粘膜下筋層から発生したと考えられる骨盤内デ スモイドの1例を経験したので報告する.

症例

患者：50歳，女性.

主訴：右繁部腫瘤触知.

家族歴：特記すべきことなし．

既往歴：18歳時, 虫垂切除術.

現病歴：平成13年夏頃より，右孯部に柔らかい腫瘤 を触知していた。徐々に増大するため皮盧科を受診. 骨盤内腫灏と診断され，平成14年 1 月 22 日当科紹介入 院となった。

入院時現症：身長 $158 \mathrm{~cm}$, 体重 $62 \mathrm{~kg}$. 立位にて右臂 部に柔らかい鷄卵大の腫瘤を触れた。しかし, 臥位で は腫瘤を触知することはできなかった，直腸指診では 腫煬による軽度の圧排で狭窄は認めなかった。

2004 年 4 月 8 日受付 2004 年 5 月 31 日採用

〈所属施設住所〉

于836-8567 大车田市宝坂町 2-19-1
入院時検查成績：一般血夜検查, 生化学検查, 尿検 查では特に問題を認めなかった. CEA. CA19-9.も正 常範囲であった。

注腸透視検查：直腸の右側方からの圧排所見を認 め, 粘膜変化はなく粘膜下腫瘍様の所見を呈していた (図 1).

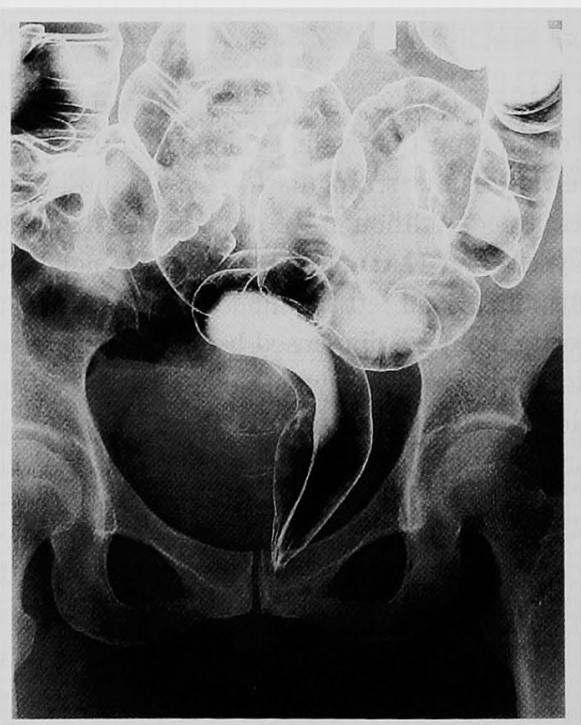

図 1 注腸造影検査：直腸右側からの圧排像を 認めた。 

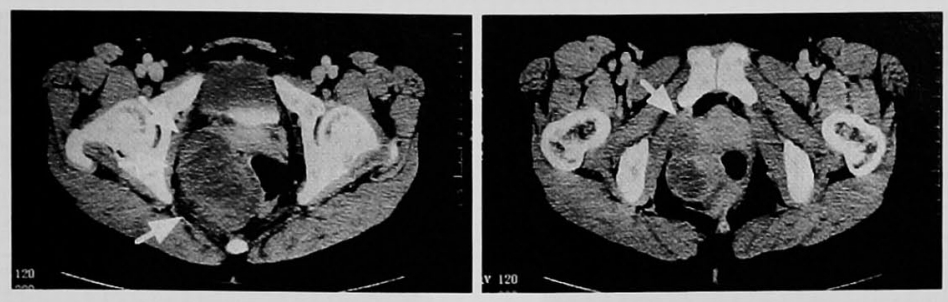

図 2 骨盤 CT 検査：直腸との境界は保たれているが，一部 (右側) 境界不明瞭な 部分を認めた。

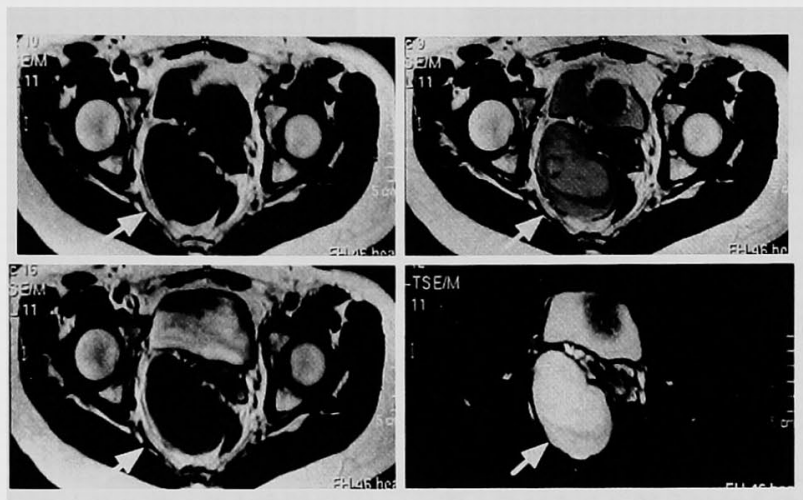

图 3 骨盤 MRI 検查：腫場は T 1 強調画像で低信号, T 2 強調画像 で軽度高信号を呈した。

$$
\begin{array}{c|c}
\text { T 1 WI } & \text { T 2 WI } \\
\hline \text { enhance(Gd) } & \text { STIR }
\end{array}
$$

大腸内視鏡検查：粘膜の伸展性は良好で，明らかな 圧排像はみられなかった。

骨盤 CT 検查：直腸右側に約 $8 \times 5 \mathrm{~cm}$ 大の腫瘤を 認めた。内部に不均一な造影効果をもち，直腸とは layerが保たれていると診断したが，尾側方向では肛 門管との境界が不明瞭な部分があり，一部直腸への浸 潤も疑われた（図2）。

MRI 検査： T 1 強調画像で軽度高信号, T 2 強調画 像ては高信号を呈し内部には隔壁と思われる線状の低 信号が多数みられた。隔壁は造影効果を有していた。 MRIにても肛門管右側壁との境界が不明瞭であった

（図 3 )。術前検查より, 直腸の粘膜下腫場, 脂肪腫, 脂肪肉腫, 緎維腺腫, gastrointestinal stromal tumor などを考えたが確定診断をつけるまでには至らなかっ た。なお，播種の危険性を考えて経直腸針生検は行わ なかった。

手術所見：下腹部正中切開で開腹した。腫場は腹膜 翻転部より下にあり，翻転部を切開したところ，直腸 癌取扱い規約でいうところの $\mathrm{Rb}$ から $\mathrm{P}$ にかけての直
腸右側に可動性良好な弾性軟の腫瘍を認めた。一部に 直腸と強く癒着している部分もあり，直腸の粘膜下腫 瘍のような形態をとっていた．切除は肛門挙筋を一部 切除し，直腸を損傷することなく腫瘍切除を行えた。

摘出固定標本 : $14 \times 9 \times 5 \mathrm{~cm}$, 三角錐様の形をした 白色調の腫瘤で割面は充実性であった。出血，壊死な どは認めなかった（図4）。

病理組織所見：分化した繊維芽細胞と膠原瀻維の堌 殖と豊富な結合組織からなっており，一部既存の筋組 織に浸潤性の発育を示す部位が認められたが，核分裂 像は認められなかった。アアチンン染色で残存した筋肉 と血管壁が陽性であった（図 5 )。

以上より骨盤内デスモイドの診断を得た。

術後経過：特に合併症なく経過し，30病日に退院。 現在, 術後 2 年 6 力月経過しているが再発の兆候なく 外来でフォロー中である。

\section{考 察}

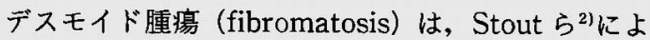
り，1）分化した線維芽細胞の増殖，2) 細胞間に膠 


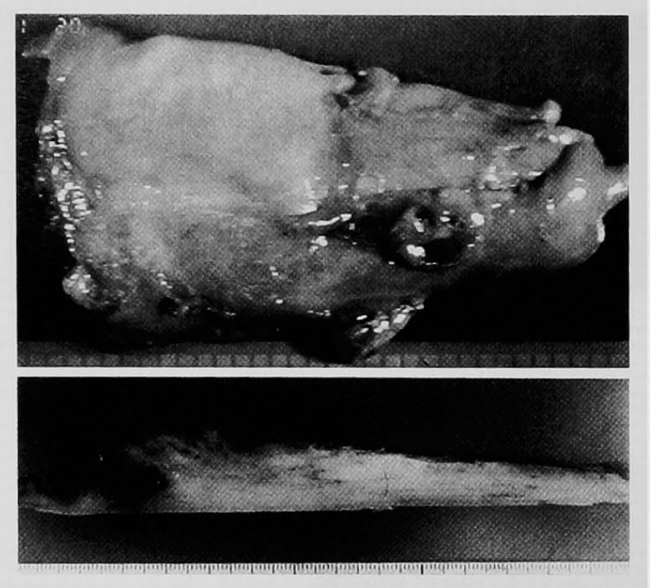

図 4 摘出標本
原線維の存在．３）浸潤性発育形態を示す．4）悪性 所見を欠く，5）転移はないが局所再発がある，と定 義された。

発生部位によって, 腹壁デスモイド, 腹壁外デスモ イド，腹腔内デスモイドの 3 つに分類されている。腹 腔内デスモイドは更に二つに分けられ，腸間膜デスモ イドそして本症例の骨盤内デスモイドに分けられてい る.

腸間膜デスモイドは報告例も多く，浸潤性に発育し イレウスや穿孔をきたす，骨盤内デスモイドは稀で， 膀胱, 臸, 直腸, 腸骨動静脈などの周囲組織に浸潤す ると圧迫症状が現れる ${ }^{3)}$. 本症例では，これだけ大きい 腫瘍にもかかわらず, 便秘などの消化器症状が全くな かったのは腫暘が柔らかく可動性が良好であったため と考えられた。

また本症例の発生部位に関しては，本来デスモイド は筋, 筋膜, 腱膜から発生し浸潤性の発育することを 考えると, 術中所見, 並びに摘出病理組織で筋肉が共 に切除されていることからして, 肛門挙筋付近から発 生し, 直腸を圧迫するように浸潤性に発育し, 粘膜下 腫瘍様の形態を示したものと考えられた。

デスモイドが腹腔内，骨盤内腫瘍として発生した場 合, 術前に確定診断をつけることは困難で, 針生検が 有用であったとの報告があるが4，本症例では播種の 危険性を考え施行しなかった。デスモイド腫瘍に対し て腹腔鏡で確認した症例で port site からの播種を認 め死亡した例もありら，今回, 針生検を行わなかったこ とは結果的に良かったのではないかと考えている，治

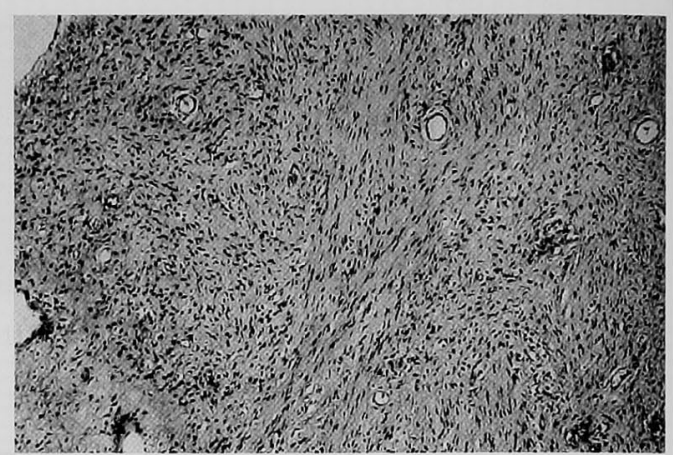

図 5 病理組織所見 $(H \& E$ 染色 $\times 40)$ ：織維芽細胞の增 殖と豊富な結合組織からなる，核分裂像は惊とんど認 められない.

療は完全摘出が原則であるが677, 周囲臟器に浸潤性に 発育するため, 他藏器との合併切除を行う症例や切除 不能症例も少なくなく，また，完全摘出が困難な場合

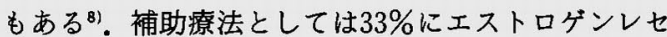
プターを認めるという報告や閉経後に腫場が自然消退 した報告より，抗エストロゲン療法が有用であるとの 報告がある ${ }^{899}$. 本症例では，患者さんにその旨をお話 ししたが，抗ホルモン剤は嫌だとのことで施行してお らず，腫場の receptor も測定はしていない。また，切 除不能例に対して放射線療法 ${ }^{101-13)}$ や化学療法として doxorubicine (adriamycin $90 \mathrm{mg} / \mathrm{m}^{2}$ ) が著効した症例 $p^{14)}$ doxorubicine $に$ Dacarbazin, Carboplatin $に よ$ る多剤併用療法が有用であった症例も報告されている が15)確立されたものはない.

再発率は25～57\%と高率であり，大部分の再発は術 後 2 年以内におこることが多い ${ }^{16}$. 悪性化の報告は稀 である゙.

このように，病理学的には良性の範儔であるが，臨 床上は再発を認めることがあり，難治性である，本症 例は完全摘出が可能であった症例だが, 再発した場合, 人工肛門を余儀なくされる可能性が高く，今後いかに 再発を予防するか, また, 再発の早期発見のための厳 重なフォローがこれからの課題である.

\section{結 語}

直腸近傍から発生し，直腸を圧迫し粘膜下腫瘍の形 態を呈した骨盤内デスモイド腫瘍の症例を若干の文献 的考察を加え報告した。 


\section{文 献}

1）遠城寺宗知：軟部腫癔. 石川栄世，牛島 有，遠 城寺宗知編, 外科病理学, 第 2 版, 文光堂, 東京, 1988, p926-931

2) Stout AP, Lattes $R$ : Tumors of the soft tissues. Atlas of Tumor Pathology, 2nd Series, Fascicle 1, Armed Forces Institute of Pathology, Wa. shington DC, 1967, p451-454

3）小松渞二，大矢正俊，小島誠人他：放射線治療で 著明な縮小をみた骨盤内デスモイドの 1 例。日本 大腸肛門病会誌 $51: 925,1998$

4）伊藤宏之，清水 哲，更級麻子他：腸間膜デス乇 イド尰瘍の 1 例. 日消外会誌 $30: 430,1997$

5）馬場正三，小里俊幸：家族性大腸腙腫泟における 長期経過からみたデスモイド腫瘍の取り扱い。胃 と腸 $32: 577-584,1997$

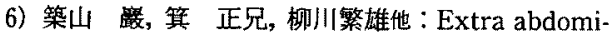
nal desmoid tumor $の 1$ 治験例. 癌の臨 30 : $1693-1699,1984$

7) 小池茂文, 田辺 博, 福富督他: Desmoid Tumor 05 例。日臨外医会誌 $47: 204-211$, 1986

8）上泉 洋，佐藤直樹，三澤一仁他：再発を繰り返 し悪性化した巨大骨盤腔内デスモイドの1例，日 臨外医会誌 $51 ： 1354-1358,1990$

9) Lim CL, Walker MJ, Mehta RR, et al: Estrogen and antiestrogen binding sites in des- moid tumors. Eur J Cancer Clin Oncol $22: 583$ $-587,1986$

10) John A, Jelinek $K$, JStelzer, et al : The efficacy of radiotherapy as postoperative treatment for desmoid tumors. Int J Radiat Oncol Biol Phys $50: 121-125,2001$

11) Matthew $T$, Gunar KZ, Allan P:Radiation theraphy in the management of desmoid tumors. Int J Radiat Oncol Biol Phys 42: 1007 $-1014,1998$

12) Bataini JP, Belloir C, Mazabraud A, et al: Desmoid tumors in adults: the role of radiotherapy in their management. Am J Surg 155 : 754-760, 1998

13) Raitamo JJ : The desmoid tumor. IV. Choice. of treatment, results, and complications. Arch Surg 118:1318-1322, 1983

14) Patel SR, Evans HL, Benjamin RS : Combination chemotherapy in adult desmoid tumors. Cancer $72: 3244-3247,1993$

15) Schunizler M, Cohen $Z$, Blackstein $M$, et al : Chemotheraphy for desmoid tumors in association with familial adenomatous polyposis. Dis Colon Rectum $40: 798-801,1996$

16）南雲剛史, 矢部啓夫, 森岡秀夫他：Desmoid tumor の治療成績. 東日臨整外会誌 $7: 100-103,1995$

\title{
A CASE OF INTRAPELVIC DESMOID TUMOR WITH MORPHOLOGY OF A SUBMUCOSAL TUMOR OF THE RECTUM
}

\author{
Haruko HORI, Takafumi ONO, Masahiro KUBOTA, \\ Takayuki FUJINO, Toru HISAKA and Kazuo SHIROUZU* \\ Department of Surgery, Omuta General Hospital \\ *Department of Surgery, Kurume University, School of Medicine
}

A 50-year-old woman, whose right gluteal tumor with the size of an egg was diagnosed as an intrapelvic tumor on magnetic resonance imaging scan at the department of dermatology in our hospital, was referred to the department. After admission, colonofiberscopy, barium enema, and CT scan revealed an $8 \times 5 \times 8 \mathrm{~cm}$ tumor on the right side of the rectum in the vicinity of the peritoneal reflexion. Either of lipoma, liposarcoma, and leiomyosarcoma was likely as preoperative diagnosis, and laparotomy was performed. The tumor was present inferior from the peritoneal reflexion, and principally on the right side of the rectum, and was comparatively easily removed. The tumor was white in color, and an elastichard spherical mass. Histopathologically the tumor was mainly composed of fibroblast and chollagen fibers, and was diagnosed as desmoid tumor.

To the best of our knowledge such a desmoid tumor as that occurs in the vicinity of the rectum with morphology of a submucosal tumor like in this case has not been reported. 